\title{
HOLY OR UNHOLY ALLIANCE? POLITICAL COALITION, INTEREST ARTICULATION AND GOVERNANCE IN NEW DEMOCRACIES
}

\section{Mustapha Salihu}

Ph.D. Candidate, Peace, Conflict \& Strategic Studies

Cite this article:

Mustapha Salihu (2021), Holy or Unholy Alliance? Political Coalition, Interest Articulation and Governance in New Democracies. African Journal of Law, Political Research and Administration 4(2), 21-39. DOI: 10.52589/AJLPRAWFNVUJZB.

\section{Manuscript History}

Received: 23 June 2021

Accepted: 22 July 2021

Published: 30 July 2021

Copyright $\odot 2020$ The Author(s). This is an Open Access article distributed under the terms of Creative Commons Attribution-NonCommercialNoDerivatives 4.0 International (CC BY-NC-ND 4.0), which permits anyone to share, use, reproduce and redistribute in any medium, provided the original author and source are credited.

\begin{abstract}
Employing qualitative content analysis and building on the submissions of coalition data theories, the study ascertains the governability and extent to which Nigeria's ruling coalition, the All Progressives Congress (APC) is able to effectively aggregate various political interests and deliver on its campaign promises. Within mainstream studies, there is a consensus on the uphill task of labelling political parties as office, or policy seeking, exclusively. Nonetheless, the study argues, despite running on key programs of fighting corruption, countering Boko Haram and diversifying the economy, the APC fits the description of an office-seeking coalition. Although the party attracted key regional power brokers from two main opposition parties, the Congress for Progressive Change and Action Congress, and aggrieved members of the former ruling party, now main opposition the then ruling People's Democratic Party. Shortly after it took power in 2015, the APC could not reach a consensus on the appointment of principal officers for the $8^{\text {th }}$ National Assembly, as this was the practice. The maneuverings that led to the selection process, the uneasy relationship between legislature and executive, as well as attempts by leaders from coalescing parties to superimpose on the party which had adverse effects on the supremacy of Nigeria's ruling coalition and institutionalization of partisan party politics. While conflicts of interests are not unusual in politics, its prevalence within Nigeria's ruling coalition adversely affects the probability of the party to actualize its campaign programs, given the seeming battle for the soul of the party. However, the dissolution of the party's National Working Committee in 2020 and the constitution of the APC Caretaker committee by President Muhammad Buhari suggests, the party is making conscious attempts to reconcile aggrieved members, register new members and retrace its steps in preparation for the 2023 general election.
\end{abstract}

KEYWORDS: Political Coalitions, Party Politics, New Democracies, Governance and Interest Articulation and Party Supremacy 


\section{INTRODUCTION}

In Africa's new democracies, the opening up of the political space in the last three decades has given rise to various forms of party fission and fusion (Kadima, 2013). From pre-electoral alliances/coalitions to informal power sharing arrangements, numerous models of power sharing arrangements are increasingly becoming a feature of competitive politics across many African states. Even though evidence suggests that coalition politics in Africa's democracies are predominantly influenced by a diverse set of logic from those that inform coalitions in consolidated democracies (Nwozor et al, 2019; Resnick, 2014; Tavits, 2007; Cox, 1997; Riker, 1962). However, given their prevalence in advanced democracies, more so with parliamentary systems, discussions on political coalition within the context of advanced democracies have been extensively examined (Carroll 2004; Wiseman 2004; Kiss 2009).

Contrary to this, studies on political coalition in Africa's new democracies, are comparatively rare, though there exists a notable few (Karume, 2003; Kadima, 2006 and Kapa 2008). Their analysis tends to focus on parliamentary models and country level comparisons. Theoretically speaking, the incentive to collapse existing party structures and coalesce under presidential institutional arrangements are complex (Resnick, 2014). This is in addition to the short-lived and inconsistent history of multiparty elections in Africa. The overwhelming preference for presidential systems means power is concentrated in the executive, giving little room for power sharing arrangements. Nevertheless, the Nigerian experience shows that at different points, efforts were made by political actors to coalesce both under parliamentary and presidential systems, thereby presenting a case for examination.

To address this literary gap, the study adopts the case of All Progressives Congress (APC) Nigeria's ruling political party, to examine the phenomena of coalition politics in presidential democracy. APC was a result of a coalition of vocal regional opposition parties, the Action Congress of Nigeria (ACN), Congress for Progressive Change (CPC), All Nigeria's People's Party (ANPP), a part of All Progressive Grand Alliance (APGA), and a host of disgruntled political gladiators from the ruling People's Democratic Party (PDP) ${ }^{1}$. The focal point of discussion shall revolve around the extent to which Nigeria's ruling coalition is able to articulate the various interests of coalescing parties and the state of governance under the APC since assuming office in 2015. Put differently, interest articulation is understood as the extent to which various individual and regional interests of political actors from coalescing parties are reconciled. Governance on the other hand, denotes the extent to which governments are able to effectively manage the affairs of a state at all levels (African Peer Review Mechanism, 2019). From a political standpoint, governance is used in other times, to emphasize the administrative and managerial activities employed by governments over society (Vymetal, 2007).

To do so, the materials for analysis were obtained from secondary sources, using qualitative methods of data collection and analysis. Data collected in the form of prior literature and survey-based evidence, will serve as basis for inference and conclusion respectively. The use

1 Tukur, S. Deflection of five governors ensured victory for APC, Okorocha. May, 20, 2015. Premium Times

Newspaper https://www.premiumtimesng.com/news/top-news/183330-defection-of-5-pdp-governors-

ensured-victory-for-apc-okorocha.html 
of a secondary method is necessitated by the inability of the researcher to get first-hand information from key actors, coupled with the transformation in data collection and storage enabled by the advent of Information and Communication Technology.

The study is structured into five sections. The first examines trends in political parties and party politics in Nigeria's Fourth Republic. The second examines coalition politics in Nigeria from a historical context. The third reviews mainstream conceptual and theoretical discussions as obtained in the literature on coalition politics. The fourth delves into the contextual dynamics of Nigeria's ruling coalition, with emphasis on interest articulation and governance. The fifth highlights the theoretical implications of the findings, concludes the discussion and highlights recommendations for further studies.

\section{Political Parties in New Democracies: A Framework for Analysis}

By virtue of representative democracy, political parties are fundamental and compelling institutions of competitive polities the world over. Amongst other functions, they ordinate and aggregate public preference, within their rights as podiums for political conscription (Mccarthy et al, 2018; Ellanantranda, 2018; Adigwe, 1974). In an ideal sense, political parties assume the role of purveyors through which mass policy preferences, party programs and manifestoes find expression in governance (Animashaun, 2010; Chidi, 2015). Without them, voters would be made to contend with a variety of self-promoted candidates; seeking votes on the basis of interpersonal relationships, charisma, celebrity status or individual recognition (Janada, 2005). In Nigeria for example, Section 229 of the 1999 constitution as amended, describes political parties as formal establishments that preoccupy themselves amongst other statutory functions, mobilization of votes during elections into various executive and legislative positions as designated in the constitution (European Union Electoral Observer Mission, 2019).

Given their utility in Nigeria's electoral process, it is in order to suggest the very significance and survival of political parties is sacrosanct on its abilities to win elections. Nigeria's winner takes all democracy (Ijon, 2019), ruling parties tend to be dominant (sadeeque et al, 2017 and Ojibara, 2017) and opposition politics in ideal sense rarely exist. While a handful of factors may condition the outlook and organization of political parties, prior studies emphasize the enforcing roles of electoral systems and electoral laws on the nature and outlook of party systems (Duverger 1974 and Cox, 1997). In light of the seeming universality that dictates the application of electoral systems and laws, the very nature and behaviors of political parties are arguably influenced significantly by the prevailing practices and norms in the societies in which they operate. Put differently, political parties function within institutional constraints formal (legal binding rules) and informal (norms and socially accepted practices) and are located within the larger pictures of the societies in which they exist. As such any meaningfulness analysis of political parties should factor in the structural constraints and dynamics of the society in which they operate.

Arguably so, in the context of new democracies, often than not, political parties are not structured as 'political machines', in the sense that they lack requisite capacity and structures to effectively establish long-term partisan relations with voters (Van de Walle, 2007; Hagopain, 2007 and Lemerchand, 1971) which enables them to predict voters' behavior. Under such conditions, partisanship remains vehemently weak, parties tend to lack ideologies and are built 
around personalities as opposed to programs or manifestos. Resulting fluidity of political parties, continues to adversely affect the probability of institutionalizing competitive party politics. In the sense that, parties do not survive one electoral cycle to another without major transformations, and most cannot be distinguished from elite gatherings (Mueller, 2011; Lindberg, 2006). In the context of new democracies, emphasis is placed on individual reputations of candidates and party chieftains as against the parties they represent (Hagopain, 2007).

In lieu of their transient and fluid nature, parties in new democracies such as those in Nigeria have been referred to as patronage (Stokes, 2007; Chandra, 2007), catch-all parties (Kirchheimer, 1969; Forestiere, 2009), and prebendalism (Joseph, 2003), in amongst other terminologies. Since Nigeria's transition in 1999, the phenomena of multi-party politics in Nigeria, is characterized by indiscriminate maneuvering, alignment and realignment of political interests and forces alike. With the relative exception of the then ruling People's Democratic Party, momentary political parties and cross-carpeting politicians dominate Nigeria's political scene (Yakubu, 2019; Fashagba, 2014). The desire by political bigwigs to advance two mega parties, so as to increase their chances of capturing state power, largely informs a trend in Nigerian politics described as politics of merger, 'consensus' candidate or political coalition respectively. This is informed in part by the desire to upstage the dominant political party in power and provide an alternative platform to govern Nigeria (Nwankwo, 2015, p.53). This trend is not unexpected, because Nigeria employs the Majoritarian Electoral System, also known as plurality single member district system. Under such electoral systems, the winner is the candidate with the most votes, and losers are excluded completely from the governance process (Ijon, 2013; Mohammed, 2013).

As such, it is not unexpected that political bigwigs more often than not, tend to align with winning parties. Based on the foregone, political parties and political actors alike in Nigeria can be termed as office-seeking (see Riker, 1962; Kadima, 2013), a term used to describe parties and by extension actors who are all out to win elections. Under such arrangement, the authors argue that ideology and partisanship are second to winning majority votes during elections. Further stating that, while electoral victories are imperative to survival of political parties, with little premiums placed on ideology and partisanship and this in turn harms institutionalization of competitive party politics.

Resultantly, the most recurring decimal, which has become a central component of party politics in Nigeria, is the fact that party leadership remains nominal, docile and subservient to party chieftains who tend to double as political godfathers. From candidate selection process (see Sadeeque et al, 2017), to intra-party politics, the system is typically abused and manipulated by party financiers, mass-mobilizers and political bridge-builders who are in other times referred to as godfathers. The antic of godfatherism does not only hinder internal party democracy; it grossly affects the supremacy of political parties (Sadeeque et al, 2017), and negates any meaningful attempts at institutionalizing Nigeria's new democracy. In Nigeria's political scene, godfathers command an army of loyalists and exert their influence, which is tied to material and monetary considerations. They are political gatekeepers: they dictate who participates in politics and under what conditions (Isaac, 2005). Given its relative understanding, Isaac (2005) classifies godfather to include, geo-political (consists of highly revered regional leaders), ethnic (leaders of ethnic organizations and ethnic elites), wealthy (those with vast material wealth), political entrepreneurs (those who can mobilize and procure 
votes) and patrons (those who enters into relationship of mutual exchanges with clients). It is worthy to note that, in other times, certain individuals meet all five criteria.

Although the outcomes of the off-cycle elections in Nigeria's Southern state of Edo defies conventionalities, given the inability of erstwhile chairman of Nigeria's ruling party to deliver his preferred candidate. It would be premature to insinuate the end to political godfatherism in Nigerian politics is near. Given their utility in intra-party politics in Nigeria, their centrifugal role in brokering political coalitions on behalf of parties they represent cannot be dismissed. Against this, it is arguable that any meaningful discussion on political coalitions in Nigerian politics, is more or less one on political alignments of political bigwigs. Arguably so, the decision on whether or not to form a new party, enter into a coalition and office-redistribution amongst other perks to come with party politics, are significantly conditioned by godfathers. As such, the study suggests coalition politics are more often than not outcomes of inter-godfather politicking aimed at capturing power either by proxy or in person. The prevalence and efficiency of the godfather's model obtains within the larger picture of patronage politics in Nigeria. The overarching influence of these political actors affects the probability for institutionalization of political parties. Given the case specific nature of the study, the subsequent section examines the trends and dynamics of coalition politics in Nigeria. This is done with a view to highlighting the determinants and contextual dynamics of political historical standpoint.

\section{Overview of Coalition Politics in Nigeria}

Coalitions (pre-electoral and post-electoral) politics are comparatively new spectacles in African politics (Resnick, 2014; Kadima, 2006, 2013), more so with presidential democracies. The founding of coalitions has been lauded as a viable alternative for opposition parties looking to oust incumbent and dominant parties (Van de Walle 2006). For Oyugi (2006) it signifies a process that brings about sharing power agreements and other material benefits therewith. Orthodoxly, they occur because neither of the coalescing parties are likely to win election on their own. As such it is predominantly borne out of necessity, given that under normal circumstances no party will coalesce except in situations in which not doing so would reduce likelihood of electoral victory. Borrowing from (Saka et al, 2018 and Oyugi 2006), the study conceives political coalition to include the collapsing of party existing structures and pulling the resources together to form a new party. Given the peculiarities of presidential regimes, coalitions tend to be initiated in the period before elections, if they increase chances at electoral victory. The study identifies party dominance as a major factor that forces smaller rival parties and opposition into working together in Nigeria. This is in addition to the Majoritarian Electoral Systems as favored by the presidential system of government in place.

It is critical to highlight that coalescing or merging of parties does not necessarily equate with alliance (pre-election or post-election alliance). Alliance has been identified as the coming together of two or more political parties prior to an election if it increases their chances of electoral victory, while coalition denotes the coalescing or merger of two or more parties to work together in Parliament and/or in government on the basis of the election outcome (Kadima, 2013; Kapa et al, 2014). Furthermore, alliances tend to be temporal working arrangements, while coalitions on the other hand are much more institutionalized with 
accompanying legal and structural implications, given that political parties collapse, do away with their previous identity and become one (Saka et al, 2018 and Godbout et al, 2005).

The history of coalition politics in Nigeria can be traced to the pre-independence era (Nwankwo, 2015). Coalitions or mergers as popularly referred to in Nigeria, have occurred in the build up to and after elections. An example of the latter, obtained in the period leading to the election that marked the constitution of Nigeria's First Republic in 1960. Key regional political parties such as National People's Conference (NPC) and the National Council of Nigerian Citizens (NCNC) formed a unity government and constituted the Nigeria parliament (Joseph et al, 2017). Similarly, pre-election alliance formation was an essential component of electoral strategies deployed in the build up to first post-independence general elections of 1964 and the Western regional election of 1965. Preparatory to the election, the Northern People's Congress, NPC had entered into talks with a collection of smaller regional parties in the Western, Midwest and Eastern regions. The alliance brought about the Nigerian National Alliance (NNA) party (Saka et al, 2018). The life span of the numerous coalitions as highlighted were soon over-thrown by the military officers bringing an end to the First Republic and parliamentary system of governance in Nigeria.

Although the adoption of a presidential system of government reduces the incentive to form coalitions, (see Manning, 2005), following the conduct of the transitional elections of 1979, the National Party of Nigeria (NPN) entered into coalition with Nigerian People's Party (NPP). Both formed a post-election governing alliance that gave the NPN the needed majority at the National Legislative Assembly. The 1979-1983 alliance between the NPN and NPP is a repeat of the NPC/NCNC governing coalition of the First Republic (Wilson et al, 2017). Accordingly, Dr. Nnamdi Azikiwe of NPP, Chief Obafemi Awolowo of the Unity Party of Nigeria (UPN), Mallam Aminu Kano led People Redemption Party (PRP) and the Great Nigerian Peoples Party (GNPP) led by Alhaji Ibrahim Waziri came together and conceived Progressive People's Alliance (PPA) to counter the dominance of NPN the ruling party of the day. However, they could not strike an accord on the leadership structure and redistribution of office, which inevitably brought about the collapse of the PPA (Nwankwo, 2015; Oyewese 2013). It is worthy to note that; while the system of governance in place is crucial in informing the decision of whether or not to coalesce, the role of party leaders/godfathers is particularly key. For instance, Dr. Nnamdi Azikiwe's NPP, Chief Obafemi Awolowo's AG and UPN, Ahmadu Bello's NPC (Omodia, 2018, p. 72) all had their parties built around them and their respective ideologies. This trend has not only become socially acceptable, it is arguably the order of the day. Attempts by individuals (godfathers) to dictate the course of intra-party politics in Nigeria, continues to have significant influence on the outlook of political parties and their functions.

Laudably, transitional arrangements that accompanied Nigeria's return to democracy in 1999, introduced measures in the form of pre-registration requirements to ensure that political parties are not built around individuals as in the case of previous democratic dispensations. In pursuance of its mandate as Nigeria's electoral umpire, formerly National Electoral Commission (NEC), now Independent National Electoral Commission (INEC), demanded as requirements for formalization, aspiring parties participate in council elections and will only be registered if they secure at least 10 percent of the total votes, in at least two thirds of the states in the federation. The result of the council election showed Alliance for Democracy (AD) as having won 100 local councils, All People's Party (APP) won 182, and People's Democratic Party won 389 out of 774 local councils in the federation. Consequently, having secured over 70 per cent of the local councils cumulatively, AD, APP, and PDP, were registered and granted 
approval to participate in both state, legislative and presidential elections of February 1999 (Sadeeque et al, 2017; Katsina, 2016; Nwankwo, 2015).

The seeming dominance of the PDP at the council polls, arguably informed the first 'known' attempts by parties to coalesce in their bid to capture power from the PDP. The now deregistered AD and APP entered into a pre-election coalition in the build up to 1999 national (presidential, federal legislative) and Local (governorship and state legislative). Under the arrangement Chief Olu Falae (AD) and Alhaji Umaru Shinkafi (APP) emerged as presidential and vice candidates respectively. Having secured a total 37 percent of votes casted, the alliance lost its shot at Nigeria's top political office and collapsed afterwards (Idayat et al, 2013). Four years later, Nigeria's political elites returned to the polls, assembled under different party platforms. To thwart any possibility of electoral offset, the ruling PDP under the presidentship of Chief Olusegun Obasanjo entered into an agreement with the South-Western governors from AD to support his second term bid, in exchange they the PDP led government will guarantee a 'smooth sail' for governors and federal legislators who are also seeking re-election. The said alliance resulted in the AD not fielding a presidential candidate and supporting Chief Obasanjo's second term aspiration (Idayat et al, 2013). The chairman of AD, Senator Bola Ahmed Tinubu (Jagaban) publicly declared his support for President Obasanjo's (PDP) second term bid at a civic reception held to commemorate the visit of the president (Tokunbo, 2002).

However, in the build up to 2007 general elections the fortunes of the PDP began to turn for the worse and cracks emerged within the ruling party. In amongst other factors, Chief Obasanjo's desire to amend the constitution and run for a third term in office, made him to handpick party leaders who will support his agenda, in doing so created the first major rift and mass-exodus from the ruling party (Akindele, 2011, Alfa et al, 2017). Capitalizing on the division within the ruling party, $\mathrm{AD}$ and other small parties in western Nigeria came together to form the Action Congress (AC), the coalition had no significant impact given that the PDP recorded a landslide victory (Nwankwo, 2015). Although a handful of factors might have contributed to the dominance of PDP since 1999, the study claims the internally devised informal power sharing formula (zoning) gave the party a national outlook. Unlike the AD and APP which had regional dominance in the North and South-West respectively, the PDP has established party structures and brings together political gladiators from various federating units that make up Nigeria.

The demise of chief Obasanjo's successor, President Umaru Musa Yar'adua a Northerner in 2010 a year to general elections truncated the internal-zoning arrangement of the PDP. The decision of substantive president Dr. Goodluck Ebele Jonathan, a Southerner to run for office, in flagrant disregard for the zoning formula of the PDP, widened the division within the ruling party. As in 2007, key opposition parties the ACN and Congress for Progressive Change (CPC) an off-shot of ANPP, entered into talks to coalesce and counter the dominance of the PDP. However, the attempts like others, failed to reach a consensus on who should contest for the presidency should the coalition pull through. Often than not, this has adversely affected the viability of party coalitions (Nwankwo, 2015). Against the backdrop of ongoing discussion, it is not surprising that the numerous attempts at entering into various forms of party coalitions or alliances as interchangeably referred to in other claims has failed, given that Nigeria is a federalist state with power concentrated in the centre government. As such, anything short of winning the presidency, political parties cannot be considered as ruling given the very limited constitutional roles of the vice president (see 1999 Constitution of the Federal Republic of 
Nigeria as Amended). The incentive to coalesce remains particularly low in presidential democracies (see Linz, 1999).

Despite a record of poor success ratio, Nigeria's key opposition parties in the build up to 2015 general elections collapsed their structures and formed a single party, which eventually defeated incumbent President Goodluck Jonathan, marking the degeneration of PDP's dominance. Having failed at numerous attempts to independently capture power from the ruling PDP sixteen years to be precise, the Congress for Progressive Change (CPC), Action Congress of Nigeria (ACN), All Nigeria People's Party (ANPP) and a part of All Progressive Grand Alliance (APGA) entered into a coalition that resulted in the defeat of an incumbent president and winning majority seats in both legislative houses (Ojibara, 2017; Katsina, 2016; Idayat, 2013) in 2015. In like manner, aggrieved political bigwigs from the PDP in the likes of former vice president Atiku Abubakar, former governor of Kwara State Senator Bukola Saraki, Senator Rabiu Musa Kwankwaso, Rear Admiral Murtala Nyako amongst others joined the fold of the APC.

Given the victory of APC at 2015 general elections, resulting government officials and cabinet members were drawn from the ranks of de-registered parties (ACN, CPC, ANPP and a handful of PDP supporters). As such, before delving into discussion on governability of the coalition, subsequent sections attempt to rationalize the decision to coalesce within dominant and contending theoretical frameworks as obtained in the discussion on coalition politics. This has become imperative for two main reasons; given the poor success ratio of coalitions in Nigeria and fluidity ascribed to political parties, do existing theories satisfactorily account for the dynamics of coalition politics in Nigeria?

\section{Theories of Coalition}

Rational choice theories of coalition government, like that of anything else, suggest that theories derive from the presuppositions on what motivates the actors to act in the manner in which they do? Predominantly, theories of coalition have emphasized seeking: a central concern for rewards such as power, prestige, and place in the limelight. Some theories have used the notion of pursuit: participation in the political process in order to implement policy objectives, often linked to underlying ideological stance (Budge et al, 1986, p. 485). The former is referred to as the office-seeking coalition (Riker 1962; Kadima, 2006), and the latter policyseeking (Axelrod 1970; de Swaan 1973). Office seeking primarily pursue the goal of getting as many parties as required for majority winning seats in parliament, while latter suggests parties primarily want to see their policies enacted in society.

Owing to the centralized approach to decision making in presidential democracies such as Nigeria, the probability for policy-seeking coalitions remains low. Coupled with the near absence of program-based parties, emphasis is placed on office-seeking as a key determinant of coalition politics in Nigeria. Lending his voice, Kadima (2014) is of the view that, although policy-seeking theories appear to be relevant, they fall short in comprehensively accounting for alliance and coalition building and collapse in most of Africa's new democracies. This is because distinction of political parties from an ideological or program standpoint is rigid given the transient nature of parties in these societies. In a comparative study of five African countries - Kenya, Malawi, Mauritius, Mozambique, and South Africa, Kadima (2006, p 228) findings 
suggest ideological or program compatibility has no significant effects on the decision of whether or not to enter a coalition. Evidently, policy-seeking coalitions are much more practical in parliamentary democracies, as such fall short in accounting for coalition politics in presidential democracies.

In his seminal study, Riker (1962) suggests that political actors enter into coalitions that are just big enough to ensure a majority, but no bigger or smaller. They are driven predominantly by desire for power. This theory is conventionally referred to as office-seeking or officeoriented (Kadima 2006, p 5). Office-seeking theories suggest the principal objective of political parties is to win election into office. Further claiming that, government formation is a win-lose situation in which public offices are the benefits. (Kadima, 2014, p. 4).

It is irrefutable that the central thesis of office-seeking models is validated in Africa's new democracies. The fundamental reason for the founding of coalitions and alliances in Africa, as elsewhere, is to assume office. Nevertheless, claims that minimal winning governments carrying no excess baggage are most likely to be formed in order to maximize possible office benefits is often contradicted. Given than in Africa's presidential democracies, pre-electoral alliances rather than post-election coalitions have a tendency to be as large as possible, as this plays a key role in securing electoral victory, even when benefits maximization seems to be at stake (Kadima, 2014, p. 5-6).

Having failed in their individual attempts to upset electoral outcomes, the ACN, CPC, APGA, APP and a flock of disgruntled political bigwigs from the ruling PDP conceived the APC. Contrary to the suggestions of minimum winning coalition model (see Riker, 1962), the APC attracted an array of political gladiators with varying regional interest and personal political ambitions. The party is seen by some Nigerians, particularly in the South-South and SouthEast as a political union of North and South West (Ojibara, 2017), which is a result of the domineering roles played by Senator Bola Tinubu and now President Muhammadu Buhari leaders of the now deregistered ACN and CPC respectively. Although the victory of the APC is seen as a watershed in Nigeria's political history, soon after the election was won, various political gladiators began to pursue their individual political ambitions. While it remains to be established if there exists formal or informal consensus on office-redistribution arrangements, the irreconcilability of various interests have turned party members as factions against each other. The display of division within the ruling party, abounds in the uneasy relationship between the executive and the $8^{\text {th }}$ Assembly under the leadership of Sen Bukola Saraki president of the senate and Honorable Dogara speaker of the lower chambers.

Against this, it will suffice to claim that beyond the need to depose the incumbent, the formation of the APC lacks specific and identifiable ideologies that distinguishes it from other coalitions. Against this, office-seeking motives overwhelmingly explain the formation of coalitions in Africa's new democracies (Resnick, 2014). However, given that politicians and parties that win elections are mandated by the populace to make policies on their behalf, it will be difficult to completely dismiss the link between office-seeking and policy-seeking coalitions, in the sense that they both seek office primarily. While the office-seeking model sufficiently accounts for the formation of the APC winning coalition and the decision by aforementioned parties to coalesce, to account for the decision of estranged politicians from the ruling PDP to join the coalition, the study borrows from the behaviorist theory. The dominant assumption of behavioral theorists is that politicians are rational actors/agents whose actions are informed by 
the need to secure votes, get maximum support to secure needed votes, form government and determine policy outcomes (Saka et al, 2018; Storm, 1990).

Before moving to examining the effects of clashing individual and regional political ambition on governance, the research suggests, formation of the APC locates within the behavioral model as it does the office-seeking model. Nevertheless, the effects of policy-seeking cannot be dismissed, given that the coalition was sold to the electorate on key policy agendas of; fighting corruption, insurgency and promoting transparency in governance (Ojibara, 2018). Also, the influence of key political actors in the likes of Senator Bola Tinubu, former VicePresident Atiku Abubakar, President Muhammadu Buhari, Honorable Rotimi Ameachi amongst numerous others who prefer to work in the shadows, cannot be ignored. In his study Olowojolu (2005) suggests without the efforts of coalescing party chieftains and widespread dissatisfaction, the PDP would have won the polls and dominated the political space.

On the applicability of coalition theories, it will suffice to claim that while the office-seeking and behavioral models account for the formation of coalition in Nigeria's presidential democracy, they cannot be considered adequate. They fall short in capturing the role of social cleavages (ethnicity, race, gender), given their central role in informing voter alignment (see Manza and Brooks, 2003). A review of the APC highlights the central roles played by regional elites in mobilizing voters along ethnic and religious lines. President Muhammadu Buhari has overwhelming support in the North as Senator Bola Ahmed Tinubu has in the South-West, Atiku Abubakar in the North-East, Bukola Saraki in the North central region amongst others. Furthermore, the Western theories fail to highlight the sit tight syndrome adopted by political elites (see Olokoju, 2016). In their quest to remain in power, political elites have been known to enter into various forms of power-sharing agreements of which coalition is not an exemption. A larger picture of the determinants of political coalition in Africa's new democracies lies within the institutionalization of democracy and the capacity of the state to enforce constitutional provisions. In Nigeria for instance, there remains a heated debate on whether legislators and state governors who jump parties should forfeit their seats. Under such condition's premiums are placed on the influence of individual politicians rather than political parties. In sum, the research is of the opinion that; in addition to office-seeking behaviors of parties and politicians, the institutional constraints (formal and informal) under which parties exist play crucial roles in informing the decision of politicians and the parties they promote.

\section{Interest Articulation and Governance under APC}

The research takes issue with opinions which suggest the electoral victory of the APC in 2015, was informed by the capacity of coalescing parties to mobilize voters (Ojibara, 2017 and Olowojolu, 2015). Building on the submissions of Michel's (1942) ${ }^{2}$ Iron Law of Oligarchy, the study sides with Awofeso et al, $(2018$, p. 24) and argued that, regime change sometimes occur in history when the ruling elites become corrupt and senile, not necessarily because the masses object to oligarchic rule but would simply prefer to be ruled by another set of oligarchs. By way of making inference, it will suffice to claim that, existential realities that characterized the Nigerian polity and state of governance in the build-up to 2015 general elections was nationally unfavorable, resultantly, the masses opted for another group of oligarchy to replace the PDP

\footnotetext{
${ }^{2}$ For detailed discussion see, Michel, R, Political Parties, 1942.
} 
oligarchy. Although the mobilizing effects of the coalescing political cannot be dismissed, the electoral success of the APC arguably reflects widespread frustration and dissatisfaction with the PDP led government, especially the manner in which it handled key issues of insurgency, youth restiveness and rising unemployment figures amongst other socio-economic and political inactions (Brookings Institute, 2015). To buttress these claims, it was asserted that;

It was neither because the APC is a "different government" in ideal sense, nor because the number of members it could garnered through the merging of parties. In essence, the ruling oligarchy of the APC, just like the PDP, may later be substituted by another set of oligarchs. True to these suggestions, talks are making the rounds of a possible merger between Nigeria's main opposition party, PDP and other minority parties as they prepare to challenge the APC come 2023. It will suffice to state that, there seems to be no end in sight to the politics of mergers and coalitions in Nigeria (Awofeso and Irabor, 2018, p. 24).

On the subject matter of interest articulation within Nigeria's ruling party, the politicking that characterized the emergence of principal officers in the $8^{\text {th }}$ National Assembly marked the beginning of uneasy union between the party and its leadership of the $8^{\text {th }}$ Assembly, as well as the executive and the legislature. Surprisingly, President Muhammadu Buhari preferred not to interfere in the process and was willing to work with whoever emerged as principal officers of the legislature, even though party leaders believed the president should have influenced the process to guarantee seamless working relationship between the executive-legislative arms of government (Ojibara, 2017, p. 40). The president, through his media team, noted his preference for the choice of the party leadership, he however lauded the constitutionally bounded process (Abubakar, 2015). The leadership of the APC condemned the act as treacherous (Eziken, 2015 and Abubakar, 2015). The emergence of Senator Bukola Saraki as the president of the $8^{\text {th }}$ National Assembly also saw Senator Ike Ekweremadu from the opposition PDP emerge as deputy senate president, birthing the first bipartisan legislature in Nigeria. While the incident can be considered as favorable to deepening democratic principles and opposition politics, it signals a lacuna in party supremacy and that puts to question the ability of the ruling party to implement its plans and policies in government.

APC's criticism of their predecessor's democratic credentials in the build up to 2015 general elections, portrayed the APC as a beacon for institutionalizing democracy in Africa's most populous nation. Sadly, this effort is far from the reality, going by the havoc and downright disorder that characterized the leadership of the ousted chairman Adams Oshiomole and the process that led to the dissolution of the party's National Working Committee in June 2020. And from what transpired in the course of the crisis, it will suffice to argue the democratic credentials of the some principal promoters of the party are questionable. Given the fact that, despite the obvious subversion of the ousted chairman, some party chieftain still supports his stay in office. Furthermore, the early problem the bedeviled the APC's success despite the credentials of its leaders like President Buhari was the uneasy relationship between the executive/legislative and leadership of the party during the 8th assembly, which lingered on for unnecessarily long time, leading to defections of principal officers to the opposition PDP. In a chat with Premium Times Newspaper, Senator Bola Ahamed Tinubu claims; defectors who dumped the APC left because the party could not offer them what they wanted. Senator Tinubu's public reaction comes few weeks after the storm of defections from the ruling party, which saw at least 12 senators, 36 members of the House of Representatives and two state governors have dumped the ruling party (Busari, 2018). In another interview, Senator Tinubu was quoted as saying, they wanted automatic tickets and share of national wealth, which the 
APC could not guarantee (The Guardian, August 18, 2018). On his part, defecting Senate President Bukola Saraki cited the nepotistic and one-sided nature of appointment into key cabinet positions. In his words, everything went to Katsina (the home state of the president), Lagos (home state of senator Tinubu). Further claiming, they don't want us in their party (The Guardian, August 01, 2018). While justifying his defection to the opposition PDP, the Senate President, states his decision was unavoidably brought about by the antics of key elements and forces within the ruling APC who have given little room for peace, cooperation, inclusion and general sense of belongingness (Busari, 2018).

Against the backdrop of the above, the study suggests, the ruling party like its contemporaries place significance on key political bigwigs, given their utility in party politics. Given the fluidity of parties in Nigeria, it is not surprising that Tinubu attempted to circumvent leadership of Nigeria's ruling coalition, a move which is evident in the appointment of his loyalist to key cabinet position $^{3}$. However, given the concentration of political gladiators within the APC, his dominance has not only been challenged, a reshuffling of cabinet positions in 2019, followed by the dissolution of the party leadership, signals move to diminish his influence on Nigeria's ruling coalition. The creation of the Caretaker Committee led by the Yobe state governor affirmed president Buhari's resolve to institutionalize the party beyond the office-seeking platform to policy-oriented institutions. While some individuals from the leaderships of the defunct ACN and CPC are merely interested in controlling the soul of the party for their personal gains. This is however not unexpected, given the utility and centrifugal roles of both parties in the build up to the merger that birthed the APC in 2013. A situation which is exuberated by the premium placed on individuals as opposed to the party as an institution of political conscription. This is in addition to the absence of clearly identifiable ideology of the party cum the contextual dynamics of competitive party politics in Nigeria's Fourth Republic.

Despite recording an overwhelming victory in the 2019 general election, the APC lost key states in Nigeria's oil rich South-South, North-Western states of Sokoto and Zamfara respectively. Similarly, leadership structure within the APC has a seemingly unimpressive hold on governance, policies and appointments into offices. The party is at other times underfunded, and generally inactive. This situation has driven erosion of popular support, malcontent amongst party chieftains and may lead to probable dismemberment of disgruntled party leaders. Nearly one year into its second term in office, ranks of the nattering nabobs of pessimism have swirled, while patronages at different levels have dwindled and are slowly spinning out (Obineche, 2020). It is seemingly evident that Nigeria's ruling coalition, is but a congregation of office-seeking elites, with little or no mutual ideological preferences, with most political appointees in radical defiance to the president Buhari's ideology of transparency. Among other challenges, the principal one was the APC's failure in enforcing party supremacy as evident in the circumstances that led to the emergence of Bukola Saraki and Yakubu Dogara as Senate President and Honorable Speaker of the $8^{\text {th }}$ Assembly.

More recently, challenges of interest articulation amongst party execs, ended with party leaders obtaining injunctions and court orders, a situation that led to the dissolution of the National

\footnotetext{
${ }^{3}$ The incumbent Vice President, Prof. Yemi Osibanjo served as his Commissioner of Justice while he was governor of Lagos State. His successor, Dr. Babaraji Fashola, was appointed Federal Minister for Power, Works and Housing. Similarly, former minister for finance, Kemi Adeosun also served under his administration while he was governor between 1999-2007.
} 
working Committee, the highest body of authority within the party. While all pending court cases have since been withdrawn as part of reconciliatory efforts, the battle for the soul of Nigeria's ruling coalition seems far from over. Based on the foregoing, it is the opinion of this research that, the phenomena of party politics in Nigeria's new democracy are predominantly a result of elite permutations and interest articulations aimed primarily at attaining political power and redistribution of commonwealth along patronage lines. Often than not, they possess no ideological bearings, as such formation of political parties in such societies are conceived along social cleavages (ethnicity and religion mainly), regionalism and are fashioned around a few selected regional elites and power brokers.

On the subject of governance, it is assumed that; what parties seek to achieve matters for the way they handle the power delegated to them by the voters. Party goals also affect how we analyze and explain party behaviour (Pederson, 2012, p. 876). Against this, it is pertinent to ask why was the APC founded, to implement policies or gain political power? Although the research acknowledges the daunting task associated with labelling political parties as office or policy seeking exclusively, it also suggests that for political parties to remain relevant, they need to win elections. Given that electoral victory is closely intertwined with delegation of power to make policies, the basis for founding the APC will be examined from office and policy seeking perspectives respectively.

While it is evident that coalescing parties came together to form the APC in order to increase their prospects of victory at the polls, the APC ran its campaign on key policy issues of security, corruption and wealth creation. The party's campaign was based on the slogan "Change" and was executed in a most vindictive, abrasive and propagandistic vigor that swarmed out every message of the then ruling PDP and its incumbent President, Goodluck Jonathan (The Cable Newspaper, 2019). In the build up to 2015 general elections, the incumbent president and his party was faced with allegations of mismanagement of public funds, rising levels of insecurity, terrorism and erratic economic and monetary policies. As such it was only natural that the APC campaign highlighted the short-comings of the ruling PDP, as a means for promoting their candidate as a viable alternative. Similarly, since assuming office in 2015, the APC led government has invested significantly in empowerment programmes and a host of Social Investment Programs, notable amongst them, N-Power, Conditional Cash Transfer, Trader Moni and the likes (see, Onah et al, 2019).

Contrary to expectations, survey-based evidence from the Afrobarometer team in Nigeria, which interviewed 1,599 adult citizens of Nigeria in January-February 2020. A sample of this size yields country-level results with a margin of error of $+/-2.5$ percentage points at a $95 \%$ confidence level shows;

A majority $56 \%$ of Nigerians are of the opinion that the level of corruption in the country increased somewhat or a lot during the past year (2019). Fewer than three in 10 citizens (28\%) say the government is doing fairly well or very well in fighting corruption, half the proportion who approved of the government's performance in 2017 (59\%) (Afrobarometer, 2020, p. 1).

Another public perception survey (Buharimeter), a study by Centre for Democracy and Development (CDD) in 2016 tracked the campaign promises of the APC led government. The survey administered close-ended questionnaires across 36 states of the federation to gauge citizens' attitudes on the performance of the administration a year after assuming office in 2016. Results show, $63 \%$ of respondents concur that the government should do more in its anti- 
corruption crusade, while $37 \%$ are satisfied with the gains of the administration in the fight against corruption. The survey also assessed citizens perception of the administrations middling rating on its performance in the area of security during its first year in office $-16.5 \%$ and $21.2 \%$ of respondents rate the government's performance in the area of security as very good and good, respectively; $19.8 \%$ and $16.5 \%$ of the respondents assess the government's performance as very bad and bad, respectively; while $24 \%$ of the respondents consider the government's performance as fair (Centre for Democracy and Development, 2016, p. 27). While in the area of the economy, $79 \%$ of respondents feel the government should have done more and $21 \%$ are satisfied with the effort of the administration. On the backdrop of huge sums expended in various National Social Investment Programs (NSIPs), the inability of verifiable data on funds disbursed puts to question the sincerity of such programs. Nonetheless, it will be unfair to disregard the contextual realities that characterizes the Nigerian state upon the assumption of the mantle of governance by the APC in 2015. According to Freedom et al (2015) the challenges facing the President-Elect are mammoth and diverse as the country itself. There is no doubt, the challenges of the Nigerian state are multidimensional and cannot be addressed over a period of five years. Nonetheless, the Social Investment and Economic Policies of the APC led government resembles that of its predecessors. In the absence of data for national planning and development, policies are more often than not reactive and crafted on wishful thinking. The numerous empowerment schemes have been an avenue for patronage, given the inability to independently verify the disbursement, measure impact and track accountability. Despite the public outcry on the present security situation in the country, the APC led government has done a lot in arms acquisition and rebuilding the capacity of the military, and liberated the territories formerly occupied by Boko Haram before 2015. The bailout given to states and the Paris Club refund also changed the fortunes of Civil Servants in over 26 states that were not able to pay salaries in 2015 .

\section{APC Caretaker Committee, Interest Articulation and Governance}

The National Working Committee (NWC) of the APC was dissolved on the instance of the National Executive Committee (NEC), the highest decision-making body of the party, a National Caretaker Committee (NCC) was set up with the mandate to conduct a special national convention within six months to elect a new NWC. Although six months have since passed and the tenure of the NCC has been increased by the President to enable it achieve its mandate of reconciling aggrieved members and register new members nationwide (The Nation, 2021). The NCC has been able to attract key political bigwigs (incumbent governors and members of parliament) to defect to its fold, there is cause to suggest, the influx of decampees may prove counterproductive if interests are not aggregated effectively. Nonetheless, the NCC deserves a commendation for the feat it had achieved in its short-lived existence.

However, one thing the party must do before the national convention to elect a substantive NWC, which has now been scheduled to hold in June, is to review the laws of the party to forestall the recurrence of attempts by certain elements or groups to superimpose on the party. Seemingly, the existing constitution of the party cedes a substantial amount of power to the National Chairman as the sole administrator of the party. The loopholes in the existing constitution could be exploited to undermine any meaningful attempts to institutionalize party supremacy. Another challenge that faces the incoming leadership of the party is the issue of zoning, a practice of rotational presidency to ensure equitable redistribution of power across 
key ethnic groups. While zoning may have the potential to reconcile and aggregate interests, it could also be exploited to disenfranchise minorities or to undermine intra-party democracy. Further to which conscious efforts should be made to ensure a detribalized party leadership emerges. At this juncture, it is imperative to highlight the seeming confidence party faithful have on the leadership of the NCC. Its chairman, who also happens to be the executive governor of Yobe state, was a card-carrying member of the CPC and Ac at different times, which gives him the advantage to galvanize the support and cooperation of leaders of coalescing parties.

\section{CONCLUSION}

To begin with, it is imperative to do away with the trend of labelling political parties in emerging democracies as solely patronal. Analysis of political parties and party politics in new democracies should consider the enforcing roles of value systems and structural constraints in informing actor behavior. Secondly, the study acknowledges the intricacies that may arise from labelling political parties as office or policy-seeking exclusively. The underlying submission is premised on arguments that, while office-seeking parties are out to win elections, they are predisposed to pursue certain policies. Similarly, policy seeking parties are also unable to implement their preferred policies without seeking office. Hence, there exists a complex relationship of interdependence within the mainstream argument on why parties coalesce.

Nonetheless, the key finding of the research suggests, the constitution of Nigeria's ruling coalition All Progressive Congress derived principally by the desire to capture political power from the ruling People's Democratic Party in 2015. This behavior is not unexpected, given political actors and parties are perpetually driven by their interests as it relates to election or re-election. In addition, trends in party behavior in contemporary Nigeria suggests, political parties (opposition or incumbents), tend not to survive from one electoral cycle to another, without experiencing major structural changes in terms of leadership, composition as well as inflow and outflow of key party actors. While the cores of liberal democratic values guarantee right to lawful association, in Nigeria's democracy, political actors are open to jumping ships, decamping as popularly referred to, if it increases their chances at electoral victory or juicy cabinet positions. Former President Goodluck Jonathan, in his memoir recounting his terminal days in office; recounts, Nigerian politics bear a resemblance with primitive wars. All that matters in electoral victory, just like a game without rules (Jonathan, 2018). On this basis, the study argues, the mass of political actors who have joined the ranks of the APC, will likely join other political parties, if it increases their chance of capturing political power or securing cabinet positions.

Regrettably, the concentration of political bigwigs in Nigeria's ruling party, alongside their diverse individual aspirations, adversely affects the probability of institutionalizing party politics and enthroning party supremacy. Evidence suggests political appointment into key cabinet positions, are reflections of the domineering persona of the political bigwigs of the party. Like its predecessor, the APC has fallen short in exerting its supremacy over its affairs and the conduct of its members. At present, it seems the battle for control of the soul of Nigeria's ruling coalition, seems to be between key actors of the now deregistered Action Congress of Nigeria (ACN) and Congress for Political Change (CPC). A situation exuberated by the very nature of Nigeria's winner takes all electoral formulae. However, the appointment of the Yobe State governor as the Caretaker Chairman seems to bring stability to the party. 
On the subject matter of governance, the government has rolled out ambitious policies aimed at improving security apparatus, fight against corruption, poverty alleviation and social investment. The bulk of these policies and programs suffer from lack of institutionalization. Often than not, they seem more like wishful thinking as opposed to evidence-based, given the lack of a centralized national database which should ideally inform the formulation of public policy. It is however pertinent to note, this trend is not peculiar to the APC alone, successive governments have failed to account for the huge amount of monies allocated annually for national identification programs. However, with the constitution of the NCC, and commendable efforts of the committee to address grievances, aggregate interest and register new members, it will not be out of place to suggest the APC is retracing its step ahead of the 2023 general elections.

\section{REFERENCE}

Abubakar, M, (2015). Buhari, PDP okay Saraki, Dogara, APC rejects winners. The Guardian Newspaper, June 10, 2015. https://guardian.ng/news/buhari-pdp-okay-saraki-dogaraapc-rejects-winners/

Adeniyi, B. (2019). Pervasive Intraparty Conflict in Democratization Nigeria: Terrains, Implications and options for Resolution. AJCRI Accord.

Akindele, S. T. (2011) Intra and Inter-party post-election crisis/ feud management in a pluralistic democracy: An X-ray of the Nigeria's political landscape. African Journal of Political Science and International Relations. Vol. 5. No. 6. Pp. 287-330.

Alfa, P. I, Kamaru, Z. H and Rajanthiran, S. P. (2017). The People's Democratic Party and Nigerian 2015 General Elections: Why was it Defeated? International Journal of Peace and Conflict Studies. Vol. 4. No. 1. Pp. 28-33.

Aljazeera centre for studies https://studies.aljazeera.net/en/reports/2015/09/20159214572746450.html

Awofeso, O and Irabor, P. A. (2015). Principle of Loyal Opposition: The Case of Political Parties in Nigeria's Fourth Republic. Journal of Politics and Law. Vol. 11. No. 4. Pp. 23-38.

Aziken, E. How Saraki, Dogara Outfoxed the APC Leaders, Vanguard Editorial, June 10, 2015.

Birch, S. (2001). Electoral System and Party Systems Stability in Post-Communist Europe. Paper Presented at the Annual Meeting of American Political Science Association. SanFrancisco.

Budge, I and Laver, M. (1986). Office-Seeking and Political Pursuit in Coalition Theory. Legislative Studies Journal. Vol. 11. No. 4. Pp. 485-506.

Busari K. (Aug 20, 2018). Why Saraki, Tambuwal and others left APC-Tinubu. Premium times Newspaper, https://www.premiumtimesng.com/news/headlines/280789-whysaraki-tambuwal-others-left-apc-tinubu.html

Chege. M. (2007). Political Parties in East Africa: Diversity in Political Party Systems. Report prepared for the International Institute for Democracy and Electoral Assistance (International IDEA) as part of its global Programme on Research and Dialogue with Political Parties, (Stockholm: International IDEA, 2007), p. 21.

Cox, G. (1997). Making Votes Count: Strategic Coordination in the World's Electoral System. Cambridge: Cambridge University Press. 
De-Swaan, A. (1973). Coalition Theories and Cabinet Formation: A Study of Formal Theories of Coalition Formation, Applied to Nine European Parliament after 1918. Amsterdam: Elsevier.

Duverger, M. A. (1954). Political Parties. New York: Wiley.

Editorial, APC and its Cocktail of Challenges, Thisday Newspaper, October 18, 2020.

European Union Electoral Observer Mission. (2019). General Election Guidelines: 23 February 9 and 23 March. Abuja: European Union.

Eziken, E. (2015). How Saraki, Dogara outfoxed APC Leaders. Vanguard Nigeria June 10 https://www.vanguardngr.com/2015/06/how-saraki-dogara-outfoxed-apc-leaders/

Fashagba, Y. (2014). Party Switching in the Senate, Under Nigeria's Fourth Republic. Journal of Legislative Studies. Vol. 20. No. 4. Pp. 516-541.

Forestiere, C. (2009). Kircheimer Halian Style: Catch All Parties or Catch All Blocs. Party Politics, Vol. 15. Pp. 537-591.

Freedom, C, Christian, M and Temilola, G. (September 15, 2015). Political Economy and Security Challenges Facing President Buhari. Aljazeera Centre for Studies. https://studies.aljazeera.net/en/reports/2015/09/20159214572746450.html

Hagopain, F. (2007). Parties and Voters in Emerging Democracies . In C. B. Stokes, The Oxford Handbook of Comparative Politics, (pp. 582-603). Oxford : Oxford University Press.

Hassan, M. B. and Lamidi, K. O. (2015) The ruling party and reaction to opposition parties in Nigerian politics: Matters arising, in H. Mohammed (Ed.) The patterns and dynamics of party politics in Nigeria's Fourth Republic (pp. 144-171), Kano: Bayero University Press.

Howard, M. A and Roessler, P. (2006). Liberalizing Electoral Outcomes in Competitive Authoritarian Regimes. American Journal of Political Science, 50.

Ijon, B. F. (2019). Winner Takes-All Politics and Democratic Consolidation in Ghana's Fourth Republic. Asian Research Journal of Arts \& Social Sciences, Vol. 7. No. 4. Pp. $1-11$.

Isaac, O. A. (2005). Explaining Godfatherism in Nigerian Politics. African Sociological Review, Vol. 9. No. 2. Pp. 79-105.

Janada, K. (2005). The Challenges of Democracy, $8^{\text {th }}$ Edition, New York: Houghton Muffin Company.

Joseph, A. and Wilson, S.O (2015) Political parties and inter-party conflict in Nigeria's fourth republic, in $\mathrm{H}$. Mohammed (Ed.) the patterns and dynamics of party politics in Nigeria's Fourth Republic (pp. 123-143), Kano: Bayero University Press.

Joseph, R. (2003). State Government and Security in African Democracy and Development. African Research Review. Vol. 5. No. 2.

Kadima, D. (2014). An Introduction to the Politics of Party Alliances and Coalitions in Socially-Divided Africa. Journal of African Election. Vol. 13. No. 1. Pp. 1-24.

Kapa, M. A and Shale, V. (2014). Alliances and Coalitions and the Political System in Lesotho 2001-2007. Journal of African Election, Vol. 13. No. 1.

Katsina, A. M. (2016). People's Democratic Party in Nigeria's Fourth Republic: Nature, Structure and Ideology. Sage Open. Pp. 1-11.

Kimenyi. M. S. (2015) Africa in focus; Nigeria 2015 https://www.brookings.edu/blog/africain-focus/2015/03/31/nigeria-2015-presidential-election-significance-and-challengesahead/

Laver, M. (1974). Dynamic Factor in Government Coalition Formation. European Journal of Political Research. Vol. 2. Pp. 259-270. 
Lepsius, R. M. (2016). Marx Weber's Institutional Theory. Switzerland: Springer International Publishing.

Lindberg, S. I (2006). Democracy and Elections in Africa, Baltimore: John Hopkins University Press.

Lipset, M.S. and Rokkan, S. (1969). Party Systems and Voter Alignment: Cross National Perspectives. Toronto: The Free Press.

Mc Cathy, N and Schickler, E. (2018). On the Theory of Parties. Annual Review of Political Science, Vol. 21. Pp. 175-193.

Mitchell, P and Nyilade, B. (2008). Government formation and Cabinet Types in Cabinets and Coalition Bargaining. (Eds). Kaore Storm, Wolfeng, M and Tobjon, B, Oxford: Oxford University Press.

Moser, R. G. (1999). Electoral Systems and the Number of Parties in Post-Communist States, World Politics. Vol. 51. No. 3. Pp. 359-384.

Muhammed, U. (2013). Nigeria's Electoral System: A Challenge to Sustainable Democracy in the Fourth Republic: International Journal of Research and Development, vol. 2. Issue. 2. Pp. 567-581.

Muller, S. (2011). Dying to Win: Elections, Political Violence and Institutional Decay in Kenya. Journal of Contemporary African Studies, Vol. 29, No. 1. Pp. 99-117.

Nwankwo, J. C (2015). Politics of Merger of Political Parties in Nigeria: The Past and Present Efforts to Evolve Two Parties. Journal of Policy and Development Studies, Vol. 9, No. 2. Pp. 56-63.

Obineche, C. APC's many challenges, As long as knives dangle over 2023, The Sun Newspaper, March 25, 2020.

Ojibara, I. I. (2017). A Governing Party in Disarray: Executive, Legislative Relations under All Progressive Congress. Global Journal of Humanities and Social Sciences, Vol. 17. No. 1. Pp. 40-50.

Olokoju, A. (2014). Sit-Tight Syndrome and Tenure Elongation in African Politics. Lagos Historical Review, Vol. 14.

Olowojolu, D. (2015). The Rise of Opposition Political Party in Nigeria: The Case of All Progressive Congress (APC). International Journal of Politics and Good Governance, Vol. VI, No.6. Pp. 1-11.

Omilana, T (01 Aug, 2018). I left APC because Kwara state was marginalized - Saraki. https://guardian.ng/news/i-left-apc-because-kwara-state-was-marginalised-saraki/

Omodioha, S, M. (2015). Political Parties and National Integration in Emerging Democracies: A Focus on Nigeria. Mediterranean Journal of Social Science, Vol. 9. No. 6. Pp. 69-74.

Osaghae, E. E. (1987). Crippled Giant: Nigeria since Independence, 1998; R. Joseph, 'Democracy and Prebendal Politics in Nigeria: The rise and fall of the Second Republic. London: Cambridge University Press.

Oyeweso, S. (2013). Why past mergers failed.The Punch Newspaper, November 30.

Oyugi, O. W. (2016). Coalition Politics and Coalition Governments in Africa. Journal of Contemporary African Studies. Vol. 24. No. 1. Pp. 231-244.

Pedersen, H. H. (2012). What do Parties want? Policies versus Office. West European Politics. Vol. 35. No. 4. Pp. 896-910.

Resnick, D. (2014). Compromise and Contestation: Understanding the Drivers and Implications of Coalition Behavior in Africa. Journal of African Elections. Vol. 13. No. 1. Pp. 43-65. 
Sadeeque, A. A and Dele, B. (2017). Contending Issues in Party Politics in Nigeria: The Candidate Selection Process. Africology, Vol. 11. No. 1. Pp. 118-134.

Saka, L. (2018). The Politics of Opposition, Parties Merger and the Struggle for Power in the 2015 General Elections, Journal of Administrative Science, Vol. 16. No. 31. Pp. 197216.

Tavits, M (2007). Party Systems in the Making: The Emergence and Success of New Parties in New Democracies. British Journal of Political Science. Vol. 38. No.2. Pp. 113-133.

The Cable (January 17, 2019). Behold the 62 Failed Election Campaign Promises of Muhammadu Buhari, https://www.thecable.ng/promoted-behold-the-62-failed-2015election-campaign-promises-of-muhammadu-buhari-and-apc

The Cable https://www.thecable.ng/promoted-behold-the-62-failed-2015-election-campaignpromises-of-muhammadu-buhari-and-apc

The Guardian. (August 20, 2018). Nigeria: Saraki, Tambuwal others left APC because they wanted Automatic Ticket Says Tinubu.

Tim, L. (2007). Conflict of Interest: A Historical and Comparative Perspective. London: University of Oxford Press.

Tokunbo, A. (2002). Nigeria, Tinubu Endorses Obj for Second Term. Thisday Newspaper, November 22, 2002.

Uyi, L. (2010). Political Conflicts and Godfatherism in Nigeria: Focus on the Fourth Republic. African Research Review, Vol. 4. No. 4. Pp. 174-186.

Van de Walle, N. (2006). Tipping Games: When do Opposition Parties Coalesce? In A Schedler Eds. Electoral Authoritarianism, Boulder CO: Lynne Reinner.

Van de Walle, N. (2007). Patrons, Cleints and Policies: Patterns of Democratic Accountability and Competition, New York: Cambridge University Press.

Vymetal, P. (2012). Governance; Defining the Concept, Working Papers Fakulty mezinárodních vztahů file:///C:/Users/u/Downloads/1_2007.pdf

Yakubu, Y. (2019). Footloose Legislators: Implication of Legislative Cross carpeting on Multi Party Politics in Nigeria's Fourth Republic. International Journal of Recent Innovation in Academic Research. Vol. 3. Issue. 2. Pp. 1-8. 